\title{
En storpolitisk julefortælling
}

af RENÉ RASMUSSEN

Ved juletid 1936 offentliggjorde Flensborg Avis en julefortælling af redaktor Jacob Kronika. Fortællingen og især de tilhørende illustrationer af den kendte tegner Valdemar Møller fremmede dog ikke julefreden. Snart efter indgik fortællingen som en brik i spillet mellem de lokale nazistiske partiorganer i Slesvig-Holsten, det danske mindretal og rigsmyndighederne i Berlin.

Cand.mag. René Rasmussen, Studieafdelingen ved Dansk Centralbibliotek for Sydslesvig, viser her, hvordan det lykkedes Kronika at udnytte angrebene på julefortællingen til en lille sejr i sin kamp for mindretallets interesser.

Jacob Kronika, Flensborg Avis' korrespondent i Berlin 1932-38, havde en lyrisk åre. I 1920'erne havde han, sideløbende med sit daværende arbejde som generalsekretær for Slesvigsk Forening og redaktør af den tyskskrevne danske presse i Sydslesvig, bl.a. forfattet en række småfortællinger ${ }^{1}$ samt skuespillet Enten-eller. Det skal ikke på nogen måde påstås, at der var tale om stor litteratur, selvom Kronika selv nærede forfatterdrømme; fortællingerne og skuespillet tjente først og fremmest danskhedens nationale sag i Sydslesvig: Det er kendetegnende, at Kronikas litterære produktion formidlede den opfattelse, at hele grænselandet fra Kongeå til Ejder fra Arilds tid tilhørte Danmark, og at samtlige dets indbyggere - med mindre de da var indvandrede sydfra - var af dansk slægt, rod og blod. Meget ofte var fortællingernes klimaks det øjeblik, da det gik op for den hidtil tysksindede slesviger, at han "i virkeligheden « var dansk, ikke sjældent ved fundet af gamle breve eller dokumenter fra et ældre slægtleds hånd.

De fleste af Kronikas fortællinger var henvendt til børn. Dette var også tilfældet med en julefortælling, han skrev til Flensborg Avis' julenummer i 1936: Da alle Lysene sluktes. En lille Flensborgsk Julehistorie illustreret af Valdemar Møller, den kendte tegner, der bl.a. var fast bidragyder til Blaksprutten og Politikens daglige satiriske spalte At tænke sig med dens særprægede persongalleri. Læsere af Politiken vil nikke genkendende til f.eks. Carlo Cartophelmoes, som er én af Møllers opfindelser. 
Jacob Kronika. Foto i Dansk Centralbibliotek for Sydslesvig.

\section{Julefortællingen}

Hovedpersonen i Kronikas fortælling er drengen Alfred, en god dansk dreng af gammel flensborg-dansk håndværkerslægt, "der aldrig, trods tyskernes overmagt, havde svigtet det nedarvede danske sindelag «. Alfred er en lille spinkel og svagelig fyr med en lidt skæv skulder, men han er ædel og retskaffen, naturligvis medlem af spej- 
derkorpset. Han er sindbilledet på det danske mindretal i Sydslesvig: Lille, lidt svagelig, men ægte og trofast. Han har netop som julegave modtaget en model af Isted-løven og et indrammet billede af det danske mindretals kirke, Helligåndskirken, og det er hans bedste julegaver. Fortællingen handler om, hvorfor han nu synes det.

Historien begynder på Isted-dagen den 25. juli. I Alfreds familie er det skik at lægge en buket røde og hvide nelliker på soldatergraven på Flensborg kirkegård, en lejlighed ved hvilken man plejer at afsynge Slumrer sodt $i$ Slesvigs Jord på en sådan måde, at shjerterne knapt nok kunne rumme det væld af følelser, som strømmede fra Slesvigs jord over i slesvigernes sjæl og blod«. Det hører med til historien, at Alfreds oldefar var faldet ved Isted og hans far i verdenskrigen.

På grund af sygdom i familien bliver det Alfreds opgave at købe blomster og lægge dem på krigergraven; moderen giver ham penge med og ledsager dem med disse formanende ord: "Tag røde og hvide nelliker. Og sørg så for, at dine blomster bliver pænt anbragt. Det er en æressag, som betros dig, min ven«. Alfred cykler afsted.

På vejen til blomsterhandleren træffer Alfred sin tyske fætter, kraftkarlen Peter, der på cykel anfører en flok drenge på vej til stranden. Peter driller Alfred: Alfred bliver opfordret til at tage med ud at bade; men takker nej: "Der er et ærinde, der skal ordnes først «. Peter griner hånligt: Alfred er "en mors dreng, der ikke tør binde an med ordentlige fyre. Vi er for farligt selskab for den lille sarte dansker. Han klarer sig bedst blandt de små piger«.

Den slags kan en rigtig dreng naturligvis ikke lade sidde på sig, og Alfred cykler med. Fætter Peter sætter et rasende tempo op ad bakkerne, "han skelede engang imellem til fætteren. Kunne Alfred virkelig klare denne tørn? Alfred klarede den. Men det kneb. Hans hjerte hamrede. Godt, at mor og bedstemor ikke så ham. Egentlig var det ham forbudt at køre op ad de stejle bakker. Men det manglede bare, at fætter Peter skulle få anledning til at håne ham! Alfred skulle vise fætteren, at den lille godt kunne være lige så stærk som den store«.

Ankommet til stranden klæder de om; de betroede midler, én mark, lægger Alfred i sit spejdertørklæde. Efter at have badet får drengene lyst til is, og Alfred bliver presset til at give fætteren sin mark - som et lån til is. Returpengene, der kun beløber sig til 20 pfennig, hvor fætter Peter ellers havde lovet kun at bruge de 50, brænder i Alfreds hånd: han "tænkte på Isted-dagen og på moderens ord: Det er en æressag, som betros dig, min ven«. Da Alfred vil forlade fætteren og 
hans kammerater, har én af dem fjernet hans spejdervimpel fra cyklen. Han vender sig imod drengene: »Han stod med knyttede næver. Hans store øjne tindrede af anspændthed og vrede. Sådan havde de andre drenge aldrig set den lille stilfærdige fyr«. Det viser sig, at to af fætter Peters venner for sjov har kastet den op i et træ. "Den, der har anbragt vimpelen deroppe, henter den også ned igen. Og det lige med det samme! Alfred talte $i$ en bydende tone, som man aldeles ikke var vant til at høre fra hans side«. Fætter Peter bliver alligevel lidt imponeret over Alfred, men Christian, synderen, udbryder: »Bliver du fræk, lille dansker? «.

Det kommer til slagsmål mellem de to, men kraftkarlen Christian har til de andre drenges forbavselse og respekt store problemer med at klare splejsen Alfred: "De to brydere væltede om i græsset. Alfred slog baghovedet mod en af de store stene, der lå i strandkanten. Det sortnede for hans øjne, men han gav ikke op. Det er en æressag, min ven sagde en røst inden $\mathrm{i}$ ham. I årenes løb havde han slugt en masse små drillerier. De store drenges fysiske overlegenhed havde pint hans følsomme sjæl. $N u$ kunne det være nok! Han var blevet ægget til kamp. Om det så gik godt eller galt, $n u$ skulle tænderne bides sammen «. Det lykkes Alfred at få Christians skuldre til jorden, og Alfred erklæres af de andre drenge som vinder: "Fint klaret, lo Peter, og rakte fætteren en næve“. Christian må hente vimpelen i træet og drengene cykler hjem. Alfred er dog noget omtumlet, han har svært ved at styre cyklen - og på Havretorv bliver han ramt af en bil. Han indlægges på sygehuset.

Her har den bevidstløse Alfred en mærkelig drøm: Det er jul, og på vej til sin tante med en gave, ser Alfred i blomsterhandelens vindue en buket røde og hvide nelliker: "Isted-dagen! Isted-dagen! Lød en røst i hans samvittighed «. Bag ruden ser Alfred også en kutteklædt skikkelse, der stirrer bedrøvet på ham. Alfred flygter, men med ét står manden ved siden af ham: "Jeg er Sunke Kulle, sagde den gamle mand med en mild stemme. Der er mig, der har bygget Helligåndskirken. Jeg er en del af denne bys historie. Overalt, hvor det danske mindes og æres, der holder jeg til; der har jeg min glæde og min fred. Jeg værner om kirke og skole. Og jeg værner om de danske soldatergrave på den gamle kirkegård «. Sunke Kulle bebrejder Alfred sommerens forglemmelse: "Din mor betroede dig en æressag; var du hendes tillid værdig? Er du en ærlig dansk dreng?«. Sunke Kulle formaner Alfred: »Tror du, at du vil kunne holde jul sammen med din 
mor og din bedstemor, så længe sandheden ikke er kommet frem? Det kan du ikke Alfred. Det kan intet menneske. Har du fejlet, så må du ærligt bekende. Ellers dør din sjæl; ellers mister du alt, som du holder af og som du tror på«.

Dette er, i parentes bemærket, nøje i overensstemmelse med Kronikas egen kristne livsholdning, der i 1930'erne var stærkt præget af både Oxford-bevægelsen og Bekenntniss-kirche.

Alfred er dog ikke helt overbevist, men begiver sig efter at have afleveret gaven til sin tante til Helligåndskirken for at overvære gudstjenesten; han ser lysene og hører orgelet, men i det samme han træder ind, går lysene ud og orgelet forstummer: "Alfreds rædselsslagne blik fortabte sig i det dybe mørke«. Atter ser han Sunke Kulle, der imidlertid blot ser på Alfred "med tunge, bedrøvede øjne. I et åndeagtigt skær". Alfred går udenfor, hører orgelet, ser lyset og går ind igen - det samme gentager sig: "Alfred kastede sig ned på gulvet. Gå! Gå! Gå! råbte han fortvivlet. Jeg vil bekende. Jeg vil fortælle mor det alt sammen. Men $g a ̊$, Sunke Kulle, for at her kan blive jul. Lad lysene blive tændt! Lad orgelet spille! «.

Scenen skifter atter - til sygehuset, hvor hans mor sidder ved sygesengen. Alfred bekender sin svare synd for sin mor, der tilgiver ham og næste jul forærer ham en model af Isted-løven og et billede af Helligåndskirken. Derfor er disse Alfreds bedste gaver!

\section{Illustrationerne}

Kronika var færdig med sin julefortælling i slutningen af november 1936, efter at have arbejdet på den i sin fritid i et par uger. Han var selv så tilfreds med resultatet, at han bad redaktør L. P. Christensen på Flensborg Avis sørge for, at der blev lavet 120 særtryk, som han kunne sende rundt med sin julepost. Han håbede på at få historien illustreret pænt, helst med billeder af Isted-løven, Helligåndskirken set ude- og indefra ved juletid, trafikulykken og Sunke Kulle ved siden af Alfred. ${ }^{2}$

L. P. Christensen tog kontakt til Valdemar Møller, der på trods af travlhed indvilligede $i$ at illustrere fortællingen. Der er grund til at antage, at han gjorde det gratis eller for en beskeden sum. Det er nemlig kendetegnende, at mange danske kunstnere gerne støttede den økonomisk og politisk hårdt trængte Flensborg Avis, efterhånden som det gik op for dem, hvilket pres, der blev lagt på avisen i det 
national-socialistiske Tyskland. Den sparsommelige ledelse på Flensborg Avis ville i øvrigt næppe have anvendt sine beskedne midler på at lade en højt estimeret og tilsvarende lønnet tegner illustrere Kronikas lille fortælling.

Møller tegnede et billede af Helligåndskirken, af Sunke Kulle, der taler til Alfred, og af optakten til slagsmålet - med den store, truende tyske dreng og hans grinende venner $\mathrm{i}$ baggrunden overfor den ranke lille Alfred. Teksten under billedet lød: »Blir du fræk, lille dansker? «.

Den forsigtige Kronika, der anede, at sidstnævnte tegning kunne give anledning til indsigelse fra tysk side, bad midt i december, kort

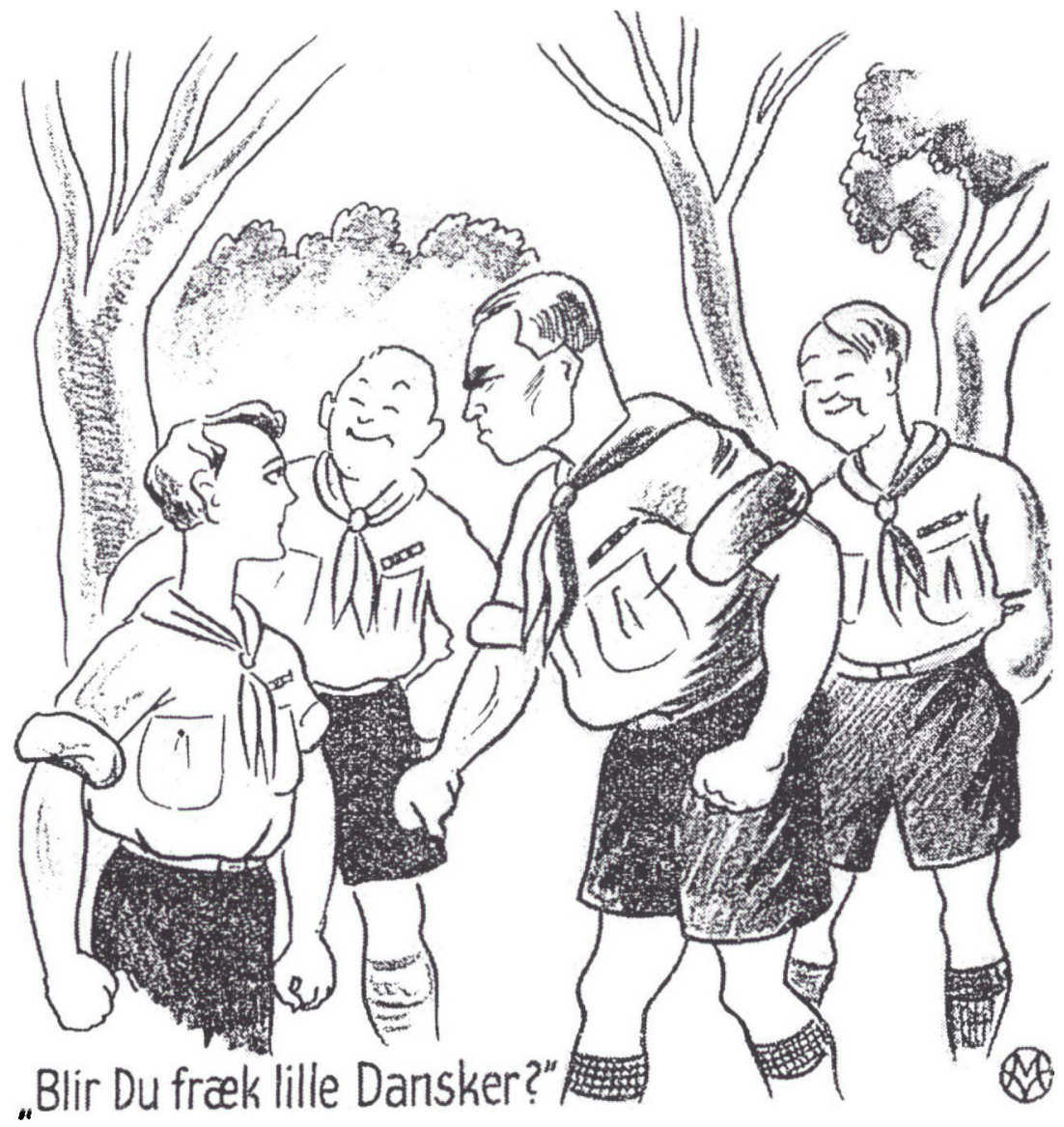

Valdemar Mollers tegning "Blir du frak lille Dansker? " til Kronika-fortallingen $i$ Flensborg-Avis-særtrykket julen 1936. 
før offentliggørelsen, om at få fjernet tegningen med de truende tyske drenge, men det lod sig af tekniske grunde ikke længere gøre; deadline var for længst overskredet, og der var ikke tid til at sætte om. I det særtryk, Kronika fik fremstillet, optræder billedet dog ikke.

Det skulle vise sig, at Kronikas bange anelser holdt stik: Ikke kun tegningen, men også - til Kronikas forbavselse - selve fortællingen, blev anledning til meget skarpe tyske angreb på Kronika og Flensborg Avis. Det førte til en række overvejelser i danske udenrigsministerielle kredse.

\section{Vrede tyske reaktioner}

Halvanden måned efter offentliggørelsen gik Nordmark-Jugend, organ for Hitler-Jugend i Slesvig-Holsten, og Flensburger Nachrichten, Sydslesvigs mest udbredte avis og siden juli 1933 et ensrettet talerør for den nazistiske stat, til frontalangreb på Kronika og Flensborg Avis. Nordmark-Jugend gav i sit februarnummer 1937 med passende bemærkninger et fyldigt uddrag af Kronikas fortælling. Indledningsvis blev det anført, at det danske mindretal og dets "ejderdanske " avis yndede at tale om "Front og Bro«, $;$ om mellemfolkelig forståelse og altid betonede sin gode vilje til at samarbejde med den tyske modpart. Man plejede imidlertid også at beskylde tyskerne og navnlig den tyske presse for at stille sig i vejen for denne forståelse, og mangfoldige gange havde Flensborg Avis beskyldt tysk presse for manglende objektivitet, ikke mindst i grænsespørgsmålet. Men hvad præsterede Flensborg Avis selv? "Tror man virkelig at tjene til fremme af forståelsen mellem de to beslægtede folk med den slags historier? Er dette det danske mindretals så ofte betonede vilje til ikke blot at være front, men også bro? Det tror vi næppe«. Det var »et stift stykke« at præsentere tyskerne for noget sådant: "Hvor ædel og tapper fremstilles ikke den lille dansker, og hvor voldelige og frække ikke de tyske?«. Ikke alene forgreb de sig på pengene til blomster til soldatergraven for at stille deres lækkersult, de tilegnede sig også uretmæssigt den danske vimpel! "Den, der har set, hvor uforstyrret det danske flag kan hejses i Flensborg, og som har set, hvorledes hagekorsflag behandles i Nordslesvig og Danmark, kan kun ryste på hovedet over den slags usande fremstillinger. Og hvor virkningsfuldt udvikler ikke den lille dansker sig til en ægte helt, der ved sej sejrsvilje triumferer over rå legemsstyrke, hvor vækkes der ikke med ulykken læsernes medlidenhed 


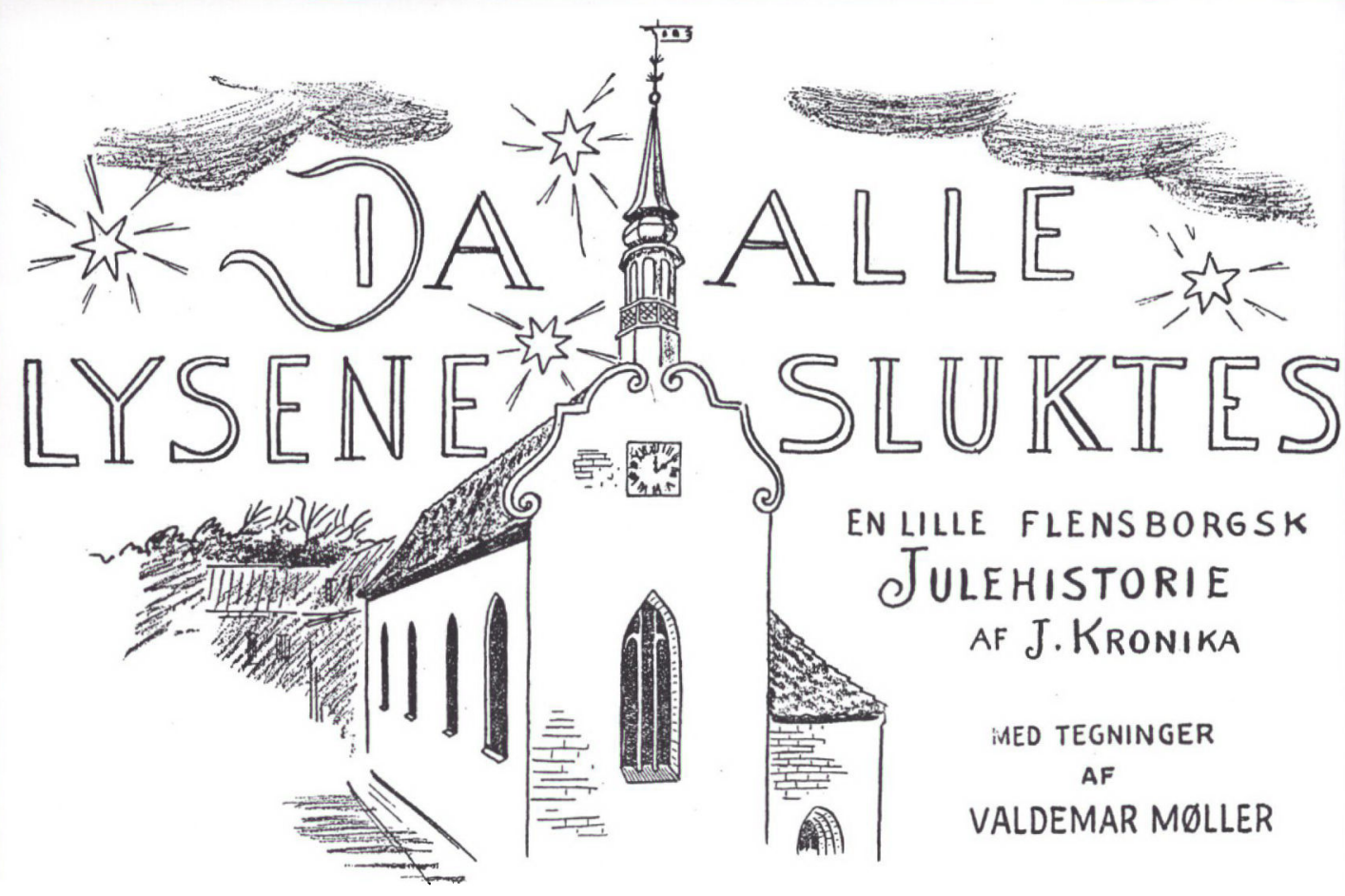

Valdemar Møllers tegning af Helligåndskirken til Kronika-fortællingen, julen 1936.

med den danske dreng og deres harme overfor de feje karle, der bærer ansvaret for ulykken«. Nordmark-Jugend var tydeligvis forarget over denne plumpe danske propaganda: "Således tegnes i en skønlitterær form typer, der skal stå tilbage i sindet som faste billeder, som typiske udtryk for dansk og tysk væsen og væremåde. Det er den gamle metode til at hetze imod et folk; man gengiver i karikeret form naboens nationale karakter, man benytter ondsindede fornærmelser og moralsk foragteliggørelse overfor modstanderen«.

Nordmark-Jugend var nok i stand til at genkende propaganda, når den så den. Noget andet ville vel også - i betragtning af bladets egen journalistiske stil - have været underligt. Det nazistiske 14-dagesskrift benyttede nemlig selv enhver lejlighed til at hetze imod det danske mindretal og den danske administration af Nordslesvig. Bladet havde netop ved årsskiftet fået ny redaktør, den tidligere grænsepolitiske redaktør af Flensburger Nachrichten, Ernst Grunow, der havde bragt de mest uhyrlige selvopfundne eller stærkt fordrejede historier fra Nordslesvig til torvs.

Men ikke alene fortællingen vakte anstød; der var også den »direkte udfordrende " illustration: "Den, der betragter de tyske drenges ansigter - eller lad os tydeligere kalde dem fjæs (»Visagen «) - denne 
blanding af gemenhed, dumhed og brutalitet, og deroverfor ser den lille danskers ædle, nordiske åsyn (»Anlitz«), aner, hvor man vil hen: Man vil bevidst forhåne vor racetanke, idet man griber til den yndede fremstilling af tyskerne som rå bastarder ("bastardierte Rohlinge«)«. Nordmark-Jugend sluttede sit indlæg med følgende salut: "Skal vi finde os i en sådan smædelse fra en avis, der udkommer på tysk grund?«. Flensburger Nachrichten sluttede sig den 18.2.1937 helt til NordmarkJugends betragtninger, idet den gav sit korte referat af Kronikas historie ekstra antitysk drejning. Den danske mindretalsavis måtte snart formanes om, at det ikke sømmede sig at forhåne og foragteliggøre værtsfolket på en måde, som ellers kun forekommer i emigrantpressen, mente Flensburger Nachrichten: "I den ovenfor omtalte fortælling viser sig ikke blot en manglende taktfølelse, men derimod den klare vilje til at forpurre ethvert forsøg på forståelse mellem folkene, navnlig blandt ungdommen. Man stiller sig selv spørgsmålet, om sådanne fortællinger egentlig ikke er rettet imod den tyske ungdomslovgivning, og kun skal tjene det formål at indpode i den danske ungdom en passende afsky overfor tysk ungdom «. Også det tyske mindretals avis, Nordschleswigsche Zeitung, sluttede sig til angrebet.

Dermed var Kronikas lille julefortælling pludselig blevet til storpolitik. Og med sidstnævnte åbne spørgsmål fra Flensburger Nachrichtens side, var et farligt emne bragt på banen.

\section{Rigsungdomsloven}

Den 1.12.1936 blev den nazistiske ungdomslov offentliggiort. Ifølge denne skulle hele den tyske ungdom sammensluttes i Hitler-Jugend, så den kunne blive opdraget $\mathrm{i}$ den rette nazistiske ånd. Der var $\mathrm{i}$ loven ikke gjort nogen undtagelser, heller ikke m.h.t. unge medlemmer af et nationalt mindretal. Kronika og generalsekretariatet indledte straks forhandlinger for at opnå undtagelse for det danske mindretal, og i det danske udenrigsministerium gjorde man sig overvejelser om, hvordan man kunne influere dansk presse til fordel for mindretallet. Forhandlingerne havde forholdsvis gode udsigter, idet Kronika havde kunnet meddele, at man i Berlin havde udtalt, at det ikke på nogen måde var hensigten at stille mindretallet ringere end hidtil. Der var i det hele taget hos de centrale instanser i Berlin en udpræget vilje til at give det danske mindretal visse særrettigheder og til at lægge låg på det dansk-tyske grænsespørgsmål. Dette skete til stor irritation og 


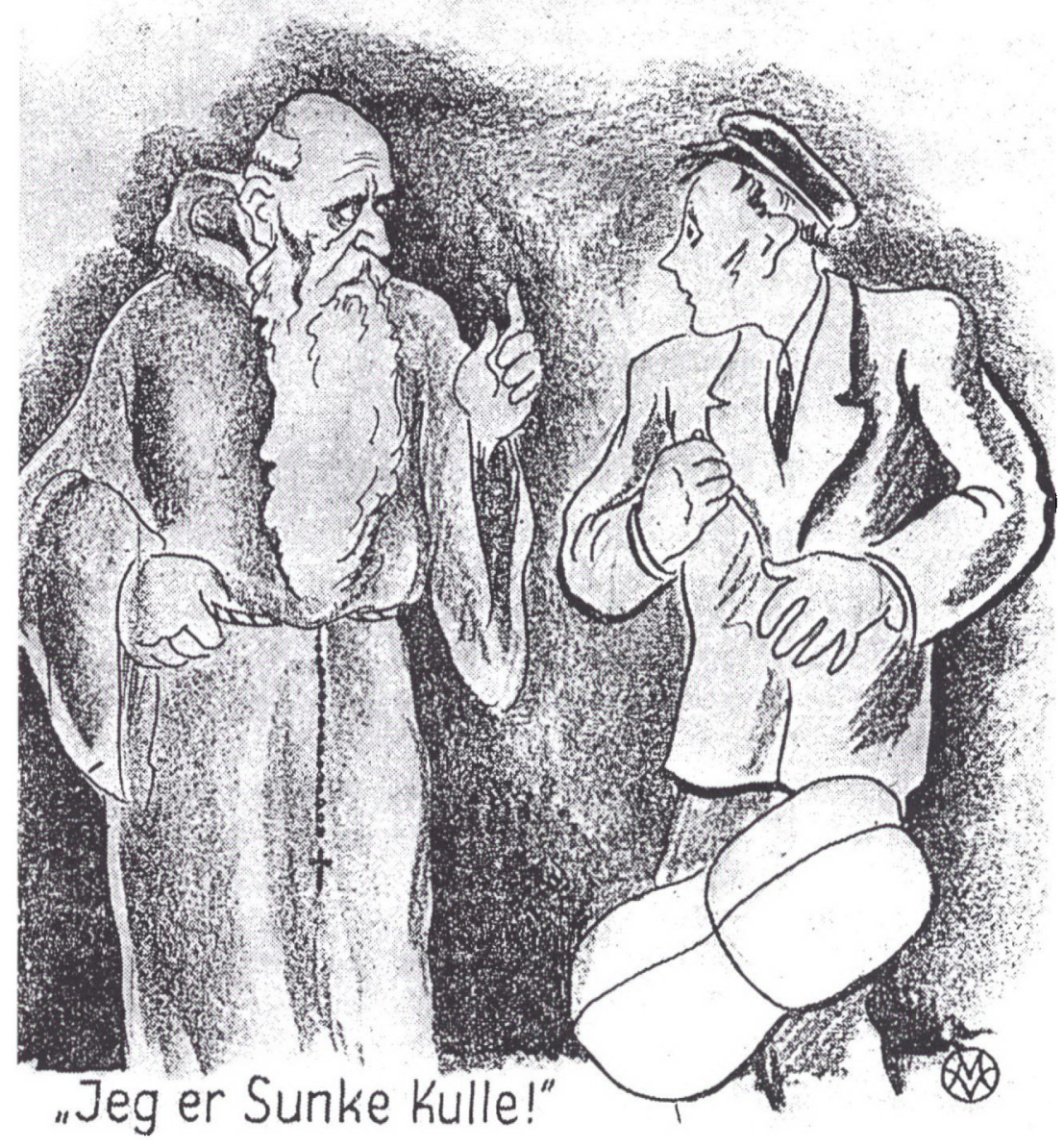

Valdemar Mollers tegning af Sunke Kulle til Kronika-fortællingen, julen 1936.

frustration for de lokale myndigheder i Slesvig-Holsten, der allerhelst ville have fuldstændigt frie hænder overfor mindretallet og tilsvarende frie hænder i propagandaen imod den dansk-tyske grænse.

Endnu inden udførelsesbestemmelserne til rigsungdomsloven var blevet udstedt, afholdt Hitler-Jugend i Slesvig-Holsten imidlertid sidst i januar og først i februar 1937 »sessioner « rundt omkring i Sydslesvig, hvori også danske børn blev indkaldt. Generalsekretariatet appel- 
lerede til Reichsjugendfiihrung, og den 18.2.1937 blev det fra HitlerJugend i Flensborg meddelt, at Reichsjugendführung havde tilkendegivet, at børn af danske forældre skulle undtages fra disse mønstringer. Endnu var intet dog afgjort, og netop i midten af februar 1937 førte Kronika vanskelige forhandlinger med rigsindenrigsministeriet og Reichsjugendführung. Alt imens oplevede Dansk Spejderkorps Sydslesvig en dramatisk tilvækst fra 120 til 267 aktive medlemmer. Forhandlingerne endte med, at der i praksis blev taget hensyn til det danske mindretals unge m.h.t. medlemsskab af Hitler-Jugend og Bund deutscher Mädel, men først i 1939 blev der udsendt egentlige undtagelsesbestemmelser for nationale mindretal. ${ }^{4}$

Det er langt fra utænkeligt, at Nordmark-Jugend og Flensburger Nachrichten midt i februar 1937 har fundet det hensigtsmæssigt at forsøge at stikke en kæp i hjulet for disse forhandlinger ved at fremstille Kronika som en forhærdet tyskerhader, der i sin lave propaganda benyttede sig af litterære børnefortællinger til at ophidse mindretallets børn og unge imod den nazistiske stat. De lokale slesvig-holstenske nazister opfattede med rette Kronikas tilstedeværelse i Berlin som en stopklods, der til stadighed forhindrede dem $\mathrm{i}$ at give de centrale myndigheder den rette forståelse af, hvordan grænselandsarbejdet burde føres!

\section{Forsvaret}

Flensborg Avis afviste den 14.2.1937 Nordmark-Jugends beskyldninger: "Bladets angreb er en forvanskning. Det fremgår i øvrigt af dets egen forkortede genfortælling. Dansk og tysk er repræsenteret af to fætre, der plejer at færdes sammen. Hvis alt, hvad der blev skrevet fra tysk side om os danske, hvis alt, hvad der stod i Nordmark-Jugend om danskheden og blandt andet om Flensborg Avis rummede så megen retfærdighedsfølelse overfor den nationale modpart som den pågældende fortælling, så ville vi være velfornøjet. Vi danske kan ikke lade være med at sporge: Hvad er meningen med de stadig fornyede truende udfald imod det danske grænseblad, oven i købet i et organ for Hitler-Ungdommen, som fremkommer samtidig med, at danske drenge og piger af Hitler-Ungdommen stævnes til mønstring?«.

Kronika mindede, forfærdet over angrebet, i et brev til Ernst Christiansen den 16.2.1937 om, at han allerede inden offentliggørelsen havde frygtet et tysk angreb, ikke p.g.a. teksten, men p.g.a. »det i 
sandhed rædselsfulde billede«, dette »frygtelige makværk«. Han havde faktisk i et brev til L. P. Christensen i december bedt om, at netop dette billede af de truende tyske drenge måtte blive fjernet, anførte han, men uden held: "Jeg kan kun endnu engang udtale min beklagelse over, at jeg imod min vilje har skullet optræde i forbindelse med uskønhed «. Billedet havde endog vakt forargelse i danske kredse, føjede han til. Når han reagerede så stærkt, skyldtes det hans i forvejen så vanskelige stilling i Berlin: »Dette er det første offentlige angreb på mig i løbet af en årrække. Jeg kan da heller ikke godt tåle den slags angreb, så længe jeg skal gøre det indviklede arbejde her på stedet. Det er æggedans dag efter dag!«. Kronika bad derfor indtrængende om mulighed for et forsvar i Flensborg Avis.

L. P. Christensen, der stod med kontakten til tegneren, mente, at Kronikas sene aflevering af manuskriptet kombineret med tegnerens store travlhed med deraf følgende sene aflevering havde umuliggiort en ændring af satsen og klichéerne - og så var skaden sket. At tegningerne var så frygtelige, rent kunstnerisk, som Kronika havde givet udtryk for, mente L. P. Christensen i øvrigt nok kunne diskuteres. Og han fandt det under alle omstændigheder ilde anbragt, offentligt at rette angreb mod Valdemar Møller, da den travle og højt lønnede tegner havde ment at vise Flensborg Avis en smuk venlighed, og han mente i øvrigt nok, at der var overensstemmelse mellem tekst og tegning; han var derfor ikke sikker på, at angrebet ikke var kommet alligevel - også uden det omtalte billede. ${ }^{5}$

Den 17.2.1936 skrev Kronika så sin forsvarsartikel, der blev offentliggjort i Flensborg Avis den 19.2.1937: "Der findes i den lille fortælling intet, som kan fornærme en tysker. Den eneste, som begår en handling, som hans samvittighed siden straffer ham for, er den danske dreng i historien «, skrev Kronika, og tilføjede, at han udmærket vidste, at drenge var så omtrent ens uanset nationalitet. NordmarkJugend forvanskede sandheden, når den påstod, at danskeren var skildret som tapper og ædel, tyskerne derimod som nogle frække voldsbrødre; "hvis denne historie er Völkerverhetzung ... så står verden ikke de næste tre dage!«. Teksten fejlede ikke noget, dog skildrede illustrationen de tyske drenge på en sådan måde, at der kunne rejses indvendinger: »Denne tegning svarer ikke til historiens ånd og tekst«, mente Kronika, og han beklagede, at tegningen var blevet offentliggiort; dette var han og ledelsen af avisen blevet enige om allerede før udgivelsen, men det havde p.g.a. tekniske vanskeligheder og en stærkt frem- 
skreden dead-line ikke været muligt at fjerne tegningen fra satsen. Kronika fastholdt, at Nordmark-Jugend havde "misbrugt et billede til at forvanske en tekst«.

På det danske konsulat i Nørregravene i Flensborg sad konsul Lauritz Larsen og ærgrede sig over historien, som de tyske blade havde gravet frem for at benytte den til et angreb på Flensborg Avis. Det gavnede ikke hans bestræbelser på at undgå kontroverser i grænselandet: »Fortællingen, i hvilken den danske dreng unægtelig fremstilles som helt overfor en tysk dreng, der forfølger ham og vil fratvinge ham penge, var blandt andet ledsaget af et billede af tegneren Valdemar Møller, på hvilket de tyske drenge tydeligt fremstilledes som brutale overfor den svage, men modige danske dreng «, indberettede han den 19.2.1937 til Udenrigsministeriet. Kronika påstod nu, at der i selve teksten intet fandtes, der kunne fornærme en tysker, men det var Larsen nu ikke helt enig med ham i. Kronika lagde desuden ansvaret over på bladets ledelse og på tekniske vanskeligheder, og underbyggede sin påstand med, at da den samme historie noget senere var blevet genoptrykt, var billedet selvfølgelig "gledet ud«. »Heldigst havde det formodentlig været, om hele fortællingen, der i sig selv ikke er noget kunstværk og nu kun giver anledning til nye tyske angreb og nyt presse-mundhuggeri, også var gledet $u d$ «, tilføjede konsulen - ikke uden malice. Det var i hvert fald mere end tvivlsomt, om de tyske blade ville tage "tekniske vanskeligheder" som en plausibel undskyldning for offentliggørelse af et billede, "som åbent erkendes at være fornærmende«. Også den danske konsul i Hamborg, Marinus Yde, følte sig foranlediget til at give sin mening til kende: »Jeg synes, at et statsunderstøttet blad skulle have tilhold om ikke at forstyrre med den slags ting «. ${ }^{6}$ Yde havde $i$ parentes bemærket under første verdenskrig været leder af det danske udenrigsministeriums pressebureau, og han havde ofte svært ved at forholde sig i ro, når dansk presse efter hans opfattelse skadede nationens interesser.

Som det fremgår, satte de to danske konsuler ikke videre pris på Kronikas lille julefortælling. Det gjorde man med sikkerhed heller ikke i det danske udenrigsministerium; her giorde man op igennem 1930'erne sit yderste for at forsøge at få dansk presse til at skrive om Tyskland og tyske forhold med forsigtighed. I udenrigsministeriet gjaldt den under tysk presselovgivning udkommende Flensborg Avis i øvrigt for at være den mest efterlignelsesværdige danske avis m.h.t. behandlingen af indre tyske forhold, men selv duksen i klassen kunne åbenbart fejle. 
Kronika sporede hurtigt i Berlin en »kedelig virkning af de tyske artikler«; han agtede imidlertid at gå til modangreb, for »det går ikke an, at jeg sluger deres bagvaskelser", skrev han til Flensborg Avis' redaktionssekretær Walter Lange den 23.2.1937.

Kronika klagede til propagandaministeriet over Nordmark-Jugends og Flensburger Nachrichtens angreb på ham og avisen og over deres, hvad han sikkert med rette opfattede som, undermineringsforsøg imod hans stilling i Berlin, og sendte breve, hvori han forklarede situationen, til flere andre tyske officielle instanser. ${ }^{8}$

I sin fire sider lange forsvarsskrivelse, affattet på tysk den 24.2.1937 og sendt til flere officielle tyske myndigheder, pointerede Kronika, at hvis de grænsetyske blades beskyldninger imod ham - der tilmed var vandret helt eller delvist over i partiofficiøse aviser - stemte, så ville han være en så samvittighedsløs og almenfarlig Journaille, at "jeg med sikkerhed ikke længere kunne være medlem af Reichsverband der deutschen Presse, at de danske aviser, jeg $\mathrm{i}$ årevis har forsynet med korrespondancer fra Berlin (Nationaltidende, Aftenbladet, Aalborg Amtstidende, Flensborg Avis og den norske Aftenposten-Oslo) måtte give afkald på mit videre arbejde som Berliner-korrespondent, at jeg måtte udelukkes fra Journalistforbundet i København, at jeg ikke længere ville blive tålt som bestyrelsesmedlem i Verein der Ausländischen Presse i Berlin«. Men beskyldningerne stemte naturligvis ikke; her var tværtimod tale om grov bagvaskelse: "Det drejer sig om et angreb på min faglige ære som journalist, der næppe kan tænkes værre havde tværtimod $\mathrm{i}$ årevis bestræbt sig på »gennem journalistisk og forfattermæssigt arbejde (Revolution, Roman om Hitlers Tyskland, Hagerups Forlag, København) at fremme mine landsmænds forståelse for Tysklands skæbne og Det tredje Riges udvikling og ånd “ [»das Werden und Wesen des Dritten Reiches"].

Dette var rigtig nok; Kronika havde, navnlig i sine første år i Berlin, været indtaget i nazismen, men var på dette tidspunkt ved at komme på andre tanker. Men havde han end lejlighedsvise skrupler ved at bruge sine overfor nazismen positive artikler eller sin roman som dokumentation for sin venlighed overfor regimet, så overvandt han dem altid for sagens skyld. Hans opgave i Berlin var nu engang at redde det danske mindretal frelst gennem Hitlertysklands udvikling, hvor den så end måtte bære hen. Det er i dette lys, hans forklaring skal ses.

Kronika kunne altså, anførte han, ikke af hensyn til sin stilling i 
Tyskland og Danmark og sit forhold til sine udenlandske kolleger lade en sådan bagvaskelse sidde på sig. Kronika tilbød at stille et særtryk af sin fortælling til rådighed for propagandaministeriets bedømmelse af sagen. M.h.t. den famøse tegning henviste Kronika til sin redegørelse i Flensborg Avis den 19.2.1937, idet han endnu engang understregede, at det var blevet forsøgt at få den fjernet fra satsen, men at dette p.g.a. tidspresset ikke havde kunnet lade sig gøre. Afslutningsvis anførte han, at Nordmark-Jugend ikke havde gengivet hans novelle loyalt, hvad enhver, der læste den i sin helhed, uden videre måtte medgive. På grundlag af sit »kendskab til det nationalsocialistiske Tyskland « kunne Kronika følgelig ikke tro, at en kampagne som Nordmark-Jugends og Flensburger Nachrichtens imod Flensborg Avis og ham personligt, kunne billiges af propagandaministeriet.

Skrivelsen til propagandaministeriet var bilagt forsvarsartiklen fra den 19.2.1937 samt en ganske overordentligt rosende skrivelse fra den danske litteraturkritiker, Hakon Stangerup, Kronikas personlige ven og kollega ved Nationaltidende, der var Kronikas egentlige arbejdsgiver. $^{9}$

Kronika skrev endvidere personligt til en række tyske aviser, heriblandt Nordmark-Jugend og Flensburger Nachrichten, og meddelte, at han $i$ anledning af angrebene på ham havde henvendt sig til ledende stats- og partimyndigheder $i$ Berlin med bøn om at ville foretage en undersøgelse og afgøre, om karakteriseringen af hans novelle og hans journalistiske indstilling med rette kunne opretholdes eller ej.

\section{Triumfen}

Sandsynligheden taler for, at man i den nationalsocialistiske tyske centraladministration har betragtet Kronikas skrivelse med en vis undren. Der er næppe grund til at antage, at man rent faktisk i Reichsministerium für Volksaufklärung und Propaganda eller Aussenpolitisches Amt der N.S.D.A.P. har givet sig selv stunder til fordybelse eller sat sig i julestemning ved at stave sig igennem Kronikas lille, på dansk skrevne flensborgske julefortælling. Man har sikkert haft andre og vigtigere ting at tage sig til. Men Kronika var en velset gæst i centraladministrationen og en respekteret udenrigskorrespondent, som man opfattede som venligsindet, selvom man var klar over, at han ikke var nationalsocialist. Man har derfor taget ham alvorligt, og faktisk taler flere ting for, at der fra centralt hold blev sendt en irettesættelse til 
den grænsetyske presse: "Mit mellemværende med de tyske blade ved grænsen vandt jeg jo. Med $100 \%$ «, kunne en glad Kronika den 19.3.1937 meddele chefredaktøren på Flensborg Avis, Ernst Christiansen. Dagen før havde en repræsentant for Alfred Rosenbergs Aussenpolitisches Amt under en frokost meddelt ham, at "man i Berlin selvfølgelig på det dybeste beklagede de uberettigede og ufornuftige angreb, og at der var gået en ordentlig epistel afsted til de tyske blade«. Også i propagandaministeriet, hvor han den 17.3.1937 havde ført en to timer lang samtale om hele stillingen i Slesvig, beklagede man de tyske presseangreb. Det var blevet ham oplyst, at man dér interesseret fulgte med $i$, hvordan de grænsetyske aviser reagerede på Kronikas brev. $^{10}$

I brevet til Nordmark-Jugend, som blev offentliggjort i Flensborg Avis den 4.4.1937, meddelte Kronika, at han havde henvendt sig »til ledende stats- og partimyndigheder i Berlin med bøn om at ville foretage en undersøgelse « og afgøre, om de tyske blades angreb på ham havde været berettiget eller ej. »Jeg har sat mig i forbindelse med officielle tyske myndigheder, der $\mathrm{i}$ årevis har kendt mig og min virksomhed, og hvis indstilling kendetegnes derved, at de til enhver tid står en journalist bi mod ugrundede angreb, også når han ikke er en tysker. Denne bistand er heller ikke blevet nægtet mig i dette tilfælde. Der er fra officiel side blevet taget afstand fra angrebene på mig «.

Dermed var sagen for Kronikas vedkommende bragt ud af verden: "Det fortsatte gode samarbejde med stats- og partimyndigheder i Berlin ligger mig overmåde meget på sinde, og, som det udtrykkelig er blevet forsikret mig, står der nu som før ikke det mindste i vejen herfor ". Han anmodede derfor om, at angrebene mod ham p.g.a. hans flensborgske novelle måtte være døde og begravede, idet han tilføjede: "Det er vel uundgåeligt, at vi slesvigere i vor nationale kamp engang slår ved siden af. Jeg selv har, hvad jeg åbent indrømmer, i de forløbne tider mangen gang båret mig fejl ad som dansker overfor tyskerne«. Nordmark-Jugends angreb måtte være forårsaget af, at deres oversætter simpelthen havde misforstået Kronikas novelle, der netop havde haft til hensigt at vise, at "der mellem børn af den fælles hjemstavn Slesvig trods forskellen i nationalt sindelag kan bestå fællesskab og kammeratskab«. Heller ikke Nordmark-Jugend kunne være interesseret $\mathrm{i}$ at modvirke forståelsen mellem de to folk. "Jeg tror fuldt og fast på Flensborg Avis' løsen, som lyder Front og Bro«, sluttede Kronika. "Så længe jeg har med politiske ting at gøre, skal det være min be- 
stræbelse efter evne at bidrage til, at kampen mellem tysk og dansk i Slesvig virkelig føres som en åndelig kulturel kappestrid. Lad os aldrig glemme de store og dybe værdier, der for os - tyskere og danskere - er fælles. Lad os kæmpe for, at vor kærlighed til hjemstavn, til folk og fædreland stadig må blive større. Så tjener hver sit eget samfund og sammen bygger vi åndelige broer, fra folk til folk".

Hverken Nordmark-Jugend eller andre af de tyske blade, der havde modtaget Kronikas brev, valgte at offentliggøre det. Det var efter konsul Larsens mening "både forståeligt og heldigt, da sagen utvivlsomt vinder ved hurtigst muligt at blive glemt . $^{11}$

Men Flensborg Avis' offentliggørelse af Kronikas brev med dets fremhævelse af hans gode forhold til myndighederne i Berlin og af uoverensstemmelserne mellem Berlin og Slesvig-Holsten var fuldt bevidst - og har sandsynligvis fremkaldt frustration og afmægtig harme på Nordmark-Jugends redaktion. Offentliggørelsen af brevet skal ses som et led i Flensborg Avis' stadige kampagne imod grænsetysk presse, for at få den til at indstille sin agitation imod den dansk-tyske grænse og sine mistænkeliggørelsesfelttog imod det danske mindretal, ved at demonstrere, at det var Flensborg Avis og mindretallet - og $i k k e$ den grænsetyske presse, der havde rygdækning i Berlin.

Det måtte Nordmark-Jugend og den øvrige tyske grænsepresse bide i sig - i denne omgang: Flensborg Avis mente lobet af april 1937 at kunne spore en ny og blidere tone i Nordmark-Jugend, hvad man ikke undlod at gøre sine læsere opmærksom på. Kronikas lille julefortælling fik virkelig for en kort stund betydning i mindretallets stadige balancegang mellem Slesvig-Holsten og Berlin.

\section{LITTERATUR OG KILDER}

Axel Johnsen: "Front og bros-løsenet under nazismens pres - Ernst Christiansen og Flensborg Avis 1938-40. Sdj.Årb. 1998 s. $133-161$.

Carsten Mogensen: Dansk i hagekorsets skygge, Flensborg 1981.

Arkivet ved Dansk Centralbibliotek for Sydslesvig (ADCB): P29, Jacob Kronikas arkiv, pk. 4: Korrespondance. E1, Flensborg Avis' arkiv, ks. 10: Korrespondance.

Rigsarkivet (RA): Udenrigsminiseriets ak- ter 1909-45 H7-283 7Y15a: Den danske presse i Syd- og Mellemslesvig. Udenrigsministeriets Pressebureau: H111160.N.204b: Flensborg Avis.

\section{NOTER}

1. Et udvalg af disse fortællinger er offentliggiort $\mathrm{i}$ Toner af Grænsesangen, København, 1947.

2. ADCB, P29-4, J. Kronikas arkiv: Kronika til E. Christiansen 16.11.1936; Kronika til L. P. Christensen 3.12.1936, 
9.12.1936; L. P. Christensen til Kronika 10.12.1936.

3. For en redegørelse for avisens "Front og Brou-lesen se: Axel Johnsen, Sdj.Årb. 1998 s. 133-161.

4. Mogensen, 1981, s. $234 \mathrm{ff}$.

5. ADCB, P29-4: J. Kronika til Ernst Christiansen 16.2.1937; L. P. Christensen til J. Kronika 18.2.1937.

6. RA, UM: H7-283 7Y15a: Konsul Larsens indberetning til UM 19.2.1937; Konsul Yde til direktor for det danske udenrigsministerium, C.C.Mohr, den 22.2.1937.

7. ADCB, P29-4: J. Kronika til Walter Lange 23.2.1937.
8. ADCB, P29-4: J. Kronika til M. Kronika 6.3.1937.

9. ADCB, E1, Flensborg Avis' arkiv, ks. 10: Kronika til Propagandaministeriet 24.2.1937 med bilag: Afskrift af $\mathrm{Ha}-$ kon Stangerups rosende artikel i $\mathrm{Na}$ tionaltidende 1.1.1937 og afskrift af Kronikas egen forsvarsartikel den 19.2.1937.

10. ADCB, P29-4: J. Kronika til Ernst Christiansen 19.3.1937, 31.3.1937, 6.4.1937.

11. RA, UMPB: H111-160 111.N.204b: Konsul Larsens indberetning til UM 5.4.1937. 